\title{
The Child's Inheritance Law Towards Business Assets in Intermarriage (Case study: The Marriage of an Australian and Indonesian Citizen)
}

\author{
I D A M Adiananda ${ }^{1}$, D A Renaningtyas ${ }^{2}$, C D Restyana ${ }^{3}$ I G E B Pratama ${ }^{4}$, N Mentari ${ }^{5}$, \\ N Alfiani ${ }^{6}$, R Puspitosari ${ }^{7}, \mathrm{~S}$ E Wulandari ${ }^{8}$ \\ \{dewa.ayu.nanda@gmail.com ${ }^{1}$ \} \\ Airlangga University, Master of Law Department, Surabaya, Jawa Timur, 60286, Indonesia ${ }^{1,2 \text {, }}$ \\ $3,5,8$ \\ Airlangga University, Master of Notary Legal Department, Surabaya, Jawa Timur, 60286, \\ Indonesia ${ }^{4}$ \\ Narotama University, Department of Law, Surabaya, Jawa Timur, 60117, Indonesia ${ }^{6,7}$
}

\begin{abstract}
Intermarriage is one of the realms of Civil International Law has choices of law in the settlement of disputes. As an example of a case in the summary this thesis, there is a dispute of inheritance in the form of a business asset placed on behalf of the wife (the mother of the heirs). The marriage was performed in Indonesia and Australia with Islamic Law and the marriage has been registered in Indonesia, this marriage also has had three sons who have different citizenship. There are several options to resolve the dispute legal heirs such as this, i.e. according to The Book of the Law of Civil Law, Australia Inheritance Law, or based on Compilation of Islamic Law. Legal issues in this study are: (1) How the child's inheritance settings in intermarriage over the business assets are put under the name (the name of) wife. (2) What is the applicable law of the resolution of disputes the fulfillment of children's inheritance in intermarriage against a business asset that is placed under the name of the wife? After the qualification against the above inheritance disputes based on legal facts which connecting factors, then the judge could determine that the Compilation of Islamic Law is the right law to use. Legitimate marriage is done according to Islamic law, then the Islamic law also applies to things of the legal consequences of marriage such as inheritance disputes. This research uses normative research methods by researching existing library materials such as legislation, books relating to law, as well as a dictionary or encyclopedia.
\end{abstract}

Keywords: Intermarriage, Inheritance, Business Assets.

\section{Introduction}

Intermarriage is a social bond that involved agents who are obedient to the divergent law. Inheritance is one of forms as a consequence of marriage law, and it includes in intermarriage. To decide a lawsuit includes in Civil International Law or Non-Civil International Law, the judge has to do lawsuit qualification. Therefore in qualified law, someone divides a law issue or a law relation what the lawsuit face, according to a known category in certain law system. 
When a lawsuit has qualified as issue in Civil International Law, it is continued to decide which a judgment will be used to solve the issue[1].

As one of the intermarriage examples, It was conducted by Mrs. Julaikah Noor Aini namely Nur Ellis (Indonesia citizen) and Mr. Robbert Kevin Ellis (Foreign named Australia citizen). The first marriage was performed in Jakarta with Islamic Law. A similar marriage was also performed in Australia when they came back to Indonesia. This marriage was registered in Indonesia. From this marriage, Mrs Nur and Mr. Robbert Ellis had 3 sons who had both Indonesia citizenship and Australia citizenship. This intermarriage was not running well, because Mrs. Nur was proved of killing her husband. This issue caused the other laws like an inheritance issue because this marriage had ended, but the wife's side did not want to spread the inheritance to her sons like business assets named of wife which it is taken place in Bali which the whole wealth earned collectively from that marriage. Like the issue which is explained above, so it will bring out several law choices to solve the inheritance intermarriage issue. To decide an issue, judge needs to focus on the points deciding which a judgment can be used, either Australia International Law or Civic International Law. Besides, which law is applied by the judge, it has to reach the aim of law namely both certain law and equitable law for the agents in the issue[2].

The objective of this research is to know the child's inheritance law system in intermarriage as business assets which named by the wife along with the inheritance to the sons who child from the inheritance which the heritance which the inheritance of business assets right is located in his mother as ownership, and to know the judgement which can obtain know you have to solve the heirs right in intermarriage toward a business assets which is disposited and handled by his mother.

\section{Method}

This research uses a juridical normative research method which means that the researcher studies determinate legislation (statute approach) according to the theories of law (conceptual approach) which is available then connected with the implementation upon the real problem. juridical normative research which is used is a research that is conducted to analyze availabe literature such as the regulation of legislation and some books related to law also dictionary or encyclopedia. The research of normative law is often named as the research of theoretician/doctrinal law. This research uses secondary data (law material)[3], [4].

\section{Result and Discussion}

\subsection{The child's Inheritance Law Regulation in Intermarriage about Business Assets}

In Indonesia, there are three kinds of inheritance law namely Islamic Inheritance Law, Customary Inheritance Law and Burgerlijke Wetboek Inheritance Law (BW). Customary Inheritance Law related to various Indonesia social lives. Indonesia citizen has patrilineal, matrilineal and bilateral characteristics. There are differences between patrilineal, matrilineal and bilateral characteristics. In patrilineal characteristics, In spite of the man and woman draw an offspring line up only through offspring of man. It differs with matrilineal who everyone draws an offspring line up only through offspring of woman. Whereas in bilateral society, everyone draws a balance offspring line through both mother and father offspring [5], [6].

There are two ways to get an inherit according to BW namely ab intestato heirs (heirs based on legislation) and testamentary heirs (heirs that are mentioned in last will and testament). Heirs which based on legislation are an heir who has blood ties both the owner heirs and heir. Family 
members of the heirs are spread in four groups. If family members in the first group are still alive, they will have a right to get all inheritance, whereas the other family will not get even a half of inheritance. If there are no family members in the first group, the family members in the second group will be the heir. Then, if there are no family members in the second group, people in the third group will get the inheritance. It also occurs to the other family from the forth group. According to $874 \mathrm{BW}$ article, the inheritance belongs to the heirs in legislation, as long as the heirs are not written in the other letters testamentary. The heirs in the letters testamentary can deviate from the determinations of legislation. But, the heirs in straight line, either up or down there is without exceptional. According to legislation, they are guaranteed by legitieme portie (absolute subdivision) [5], [6].

In Islamic Inheritance Law, this distribution process is known as fara'id, distribution of a deceased person's in according to the law sharia, a science that explains about the rules of heritages as heirs decided into two categories, namely : first as the rules of heritage distributions, second as the rule of account each part, and how to account each part in every right of the heritage distribution. The rules as the heirs are, below:[6], [7]

a. Muwarits, a deceased person leaving the inheritance which belongs to the heirs, even they passed away in haqiqy, huqmy, and taqdiry. Huqmy deceased is a death which is stated by the judge's decision in several causes, although in the reality they have not passed away yet. In hadith Narrated Abu Huraira: The Prophet said,

b. $\quad$ "If somebody dies (among the Muslims) leaving some property, the property will go to his heirs; and if he leaves a debt or dependants, we will take care of them."

c. Warits someone who has potential get the heritages from a deceased person of family. Because they have blood ties, siblings, relation or guardianship right.

d. Mauruts is the properties or wealthy left by a deceased person. Eventhough all movable or immovable property, it has to spread of right and obligation causes of death. Mauruts (heritage) is well-known as "irtsan, miratsan, and tirkatan (tirkah)". However, the reality has the same meaning, all of the properties and wealthy left by deceased for the heirs.

In reference to Australia Inheritance Law, currently it applied Succession Act 2006 Number 80. According to the regulations, it is decided that inheritance characteristics in Australia related to testament. It means that each inheritance must have either last will or testament which it helps to decide who the heirs will become and how the heritage is shared. However there are several issues, one of the issues is about the heirs without testament, how is it shared? Commonly, if a person dies and does not have family or siblings who are eligible, thus all the wealth will belong to the country. If someone climes of the wealth properties which belonged to the heirs without testament, they have to apply a letter to the Crown Solicitor. That is the point of 4.5 Succession Act 2006. Currently, the Succession Amendment (Intestacy) Act 2009 which is started on march 12010 had created section four of the Succession Act 2006. It had changed about a deceased person without testament who someone gets right for the heritage properties from a deceased person without testament.

Below are big alterations before there are no regulations about testament:

a. Giving priority for a spouse right without testament

b. Nowadays, there are several spouse concepts

c. No differences between siblings and step-siblings

d. Cousin is the first applicable inherit properties

e. Several people who are eligible according to the country, if there are no siblings who are eligible

f. Several certain rules for the customary citizen. 
The heritage properties like business assets are two kind either smooth assets or non-smooth assets. Smooth assets can be likes a money supply, short investment, business receivable, note receivable, income which will be gotten, stock, equipment stock, earlier full payment, and other related things. Whereas non-smooth assets can be likes land, building, machine, and other things If in an issue the heir is either Indonesia citizen or foreign citizen but the inheritance properties are in Indonesia, so it will use the rule of National law. For example: If the Inheritance property of business assets island, Indonesia National Law will make reference to act number 5 year 1960 about the principal of Agraria (UUPA). Ground law in Indonesia follows the exclusion principle of ground relegation (grounds verponding verbood) which forbid the grounds in Indonesia have belonged to people from non-Indonesia citizens. It related to article 26 Ayat (3) UUPA which explained if people lost their status of Indonesia citizenship because of marriage or inherit, people have to move the grounds to the third people's side, or the grounds belong to the state.

According to the Inheritance in Islamic Law, it is not contrary to Indonesia National Law. However, Islamic law also takes cognizance of jurisdiction for every side, so according to Islamic law the foreigner also can get "enjoyable" of the heritage. In the heritage properties, they get their right of heir part but can not belong it. They only have right to take the amount of the equal price from a property which be their heir parts[8]. Australia Law in Succession Act 2006 Number 80 controls who have a right being the inherited without testament is family and closed sibling. In Succession Act 2006 Number 80 there are no heirs differences based on the citizenship differences because based on the rule it explained that children are the main heirs of the inheritance wealth which is inherited by their parents.

\subsection{The available law in mediation for compliance of the child's inheritance law in intermarriage toward business assets which is put under the name of their mother.}

For the example of Ms. Nur's issues, until the writing of thesis summary, the business assets have not been inventoried. The property of business assets a deceased spouse must become the inheritance wealth for Ms. Nur and her child. To decide which law has to be used by the judge for deciding these issues, so the judge must consider the point of these issues. If it is according to the legal wedding and the location of business assets, the law which is used in lawsuit of this inheritance is Islamic law. Based on article $37 \mathrm{UU}$ marriage it does not contend about distribution of collective wealth, this article mentioned that the distribution will be done by the valid law for every person's side. As we know it, the marriage was beheld based on Islamic law, so in distribution of collective wealth as the inheritance wealth in these issues it must use the rule in $\mathrm{KHI}$.

Based on Islamic Law, there are no differences in amount of the heirs toward children from difference citizenship. But Ms, Nur as a longer spouse can not inherit legally, because she was proved killing her spouse who is the heirs in family. It is only three children as the heirs who are the children of the inheritance owner. Moreover, the mother does not want to get the business assets as the inheritance wealth, the heirs either collective of personal can bring a will to the other heirs to do distribution of the inheritance wealth toward bringing a lawsuit the Islamic court. It has been decided in the article $188 \mathrm{KHI}$. Islamic la decides that the sons will get the inheritance wealth in balance of quantity. In islamic law the sibling in these issues who are foreigners will not lose economics right toward the property which they get as the inheritance wealth. 


\section{Conclusion}

In Intermarriage, spouse and children are the absolute heirs admitted legally both in Indonesia (Islamic Law, CustomaryLaw, and Civil Law of BW) and in Australia. But, the law is valid in order to distribute the inheritance law which must be based on the judicial decision in order to reach justice and legal security as the purpose of law. If there is a lawsuit about the inheritance law, the mediation can use the law where the inheritance wealth takes place. According to the example above, related to the child's inheritance lawsuit in intermarriage which uses Islamic Law caused the marriage was done by Ms. Nur and spouse in Islamic law and has been written in Indonesia, and also the business assets being the inheritance which located in Bali, Indonesia. Ms. Nur who is the heirs' mother has made a punitive measure and punishable along with getting strength of a constant law. So, Ms. Nur has lost her inheritance right, she has lost to be the heirs. The judge can use KHI in mediation of the inheritance, it is seen from the law facts which show to use National Law to solve it.

\section{References}

[1] B. S. Hardjowahono, Dasar-Dasar Hukum Perdata Internasional. Bandung: Citra Aditya Bakti, 2013.

[2] Pengadilan Negeri Denpasar, Putusan Pengadilan Negeri Denpasar Nomor 106/Pid.B/PN Dps Tahun 2015. 2015.

[3] P. M. Marzuki, Penelitian Hukum. Jakarta: Kencana Prenada Media Group, 2017.

[4] S. Soekanto and S. Mamudji, Penelitian Hukum Normatif Suatu Tinjauan Singkat. Jakarta: Raja Grafindo Persada, 2009.

[5] B. Sunggono, Metodologi Penelitian Hukum. Jakarta: Raja Grafindo Persada, 2009.

[6] Sudarsono, Hukum Waris dan Sistem Bilateral. Jakarta: Rineka Cipta, 1991.

[7] M. A. As-shabuni, Hukum Waris Dalam Syari'at Islam. Bandung: CV. Diponegoro, 1995.

[8] W. Kuncoro, Waris Permasalahan Dan Solusinya (Cara Halal dan Legal Membagi Warisan). Jakarta: Raih Asa Sukses, 2015. 